\title{
CLINICAL EVALUATION OF DIRECT PHOTOCOMPOSITIONAL DENTAL RESTORATION IN DIFFERENT CONDITIONS OF LIGHT POLYMERIZATION OF ADHESIVE SYSTEM
}

\author{
Oleksandr Udod \\ Olena Borysenko ${ }^{1}$ \\ ndl2963@gmail.com \\ ${ }^{1}$ Department of Dentistry No. 1 \\ Donetsk National Medical University \\ 39 Mashinobudivnikiv blvd., Kramatorsk, Donetsk region, Ukraine, 84313
}

\begin{abstract}
Photocomposite materials and adhesive systems are used for direct tooth restoration, among which 5th generation systems are most often used. To ensure curing, they are exposed to the light flux of the dental photopolymerizer, but the requirements and conditions of such exposure are insufficiently studied.

The aim - clinical evaluation of direct photocomposite restorations of teeth performed using an adhesive system, the curing of which was carried out in different light conditions.

Materials and methods. 185 people aged from 19 to 44 years were examined, in which 185 lateral teeth with carious cavities of the 1st class according to Black for medium and deep caries were restored by direct method from nanophotocomposite material. In patients of group 1 during the restoration of 62 teeth the polymerization of the adhesive system of the 5th generation was performed with a light flux of constant intensity $1500 \mathrm{~mW} / \mathrm{cm}^{2}$, in patients of group 2 were restored 60 teeth with polymerization of the same adhesive system with light flux by "soft start" with a final intensity of $1500 \mathrm{~mW} / \mathrm{cm}^{2}, 63$ teeth in persons of group 3 were restored with a gradual light effect of $1500 \mathrm{~mW} / \mathrm{cm}^{2}$ on the adhesive system at the bottom and each of the cavity walls using an additional device. The state of recovery was examined after 12 and 24 months.

Results. Within 12 months, the largest total number of disorders according to the clinical criteria "marginal adhesion", "marginal staining", "postoperative sensitivity" and "secondary caries" was found in patients of agroups 1 and 2, violations were found in 10 and 13 restorations, respectively ( $16.1 \pm 4.9 \%$ and $21.7 \pm 5.8 \%$ of the number of restorations in each group). In persons of group 3, disorders were identified in 3 restored teeth $(4.8 \pm 2.6 \%)$, which is statistically significant $(p<0.05)$ better. After 24 months, statistically significant $(\mathrm{p}<0.05)$ the best indicators were again in patients of group 3 , violations were found only in 4 restorations $(6.7 \pm 3.2 \%$ of them in this period). The worst was the state of recovery in persons of group 2 , they had disorders in 20 restorations $(42.6 \pm 10.4 \%)$, in patients of group 1 - in 16 restorations $(30.8 \pm 8.0 \%)$.

Conclusions. Direct restoration of teeth from nanophotocomposite material, performed using the 5th generation adhesive system under the condition of its gradual polymerization at the bottom and each of the walls of the carious cavity of class 1 according to Black, showed high clinical efficiency, which in 12 and 24 months amounted to, respectively, $93.7 \pm 3.4 \%$ and $88.9 \pm 3.5 \%$.
\end{abstract}

Keywords: dental caries, direct photocomposite restoration, adhesive system, light polymerization.

DOI: $10.21303 / 2504-5679.2020 .001331$

\section{Introduction}

In modern restorative dentistry, photocomposite materials are used for direct restoration of teeth, which make it possible to significantly reproduce the anatomical-functional, optical and physical-mechanical characteristics of the hard tissues of natural teeth $[1,2]$. However, these materials do not have independent adhesion to hard tissues, so the role of conditional mediator, which provides a strong adhesion of the photocomposite with enamel and dentin, take adhesive systems [3]. In the dental materials market there is a certain variety of adhesive systems that are used during the restoration work on teeth or orthopedic structures [4, 5]. Unmistakable choice of adhesive system and adherence to the technology of adhesive preparation minimizes the risk of marginal fit disorders, marginal discoloration, secondary caries and other complications $[6,7]$. 
Adhesive systems are presented for eight generations, they have a wide range of indications, which allows you to work with most restoration materials, in particular, photocomposite materials, and can ensure their adhesion to the hard tissues of the teeth. Modern polymer-based adhesive systems are divided into total etching systems, which consist of two or three components, and self-etching adhesives, which are available in one- or two-stage version [8, 9]. Adhesives of all types not only create a unique joint between photocomposite materials and hard tissues of teeth, but also allow to comply with the requirements of minimally invasive preparation of cavities [10].

Regardless of the chemical composition and type of adhesive system, they all first etch and demineralize the hard tissues of the teeth to be restored [11, 12]. However, it should be noted that adhesives used after the total etching step showed longer-term stability of the enamel and dentin bond compared to self-etching adhesive systems, which showed higher adhesion to dentin and less adhesion to enamel. As a result, the connection of photocomposite material with enamel in the technique of total etching gives higher strength and significantly reduces the number of clinical disorders that may occur during the operation of such restorations [13]. Therefore, 5th generation adhesive systems in the total etching technique were used in this clinical study.

No less important is the task of ensuring the full curing of the adhesive systems used. The light exposure through which the curing process takes place must meet certain requirements. However, recommendations for the polymerization of adhesive systems contain quite general formulations, and the results of research on the intensity and direction of light flux from a light source with a certain wavelength, as well as the mode of light flux with constant intensity or increase is still insufficiently covered $[14,15]$. In addition, there are few long-term clinical trials in this area, so their results and conclusions should be significant to minimize a number of clinical complications, which, unfortunately, often occur after dental restoration using any restorative materials and adhesive systems $[16,17]$.

The aim - clinical evaluation of direct photocomposite restorations of teeth performed using an adhesive system, the curing of which was carried out in different light conditions.

\section{Materials and methods}

In a clinical prospective randomized study conducted at the clinic of the Department of Dentistry No. 1 of Donetsk National Medical University during 2017-2019 were examined 185 people aged 19 to 44 years, in which were restored 185 lateral teeth with carious lesions of 1st class according to Black with about medium and deep caries. Among those surveyed were 95 men $(51.4 \%)$ and 90 women (48.6\%). All patients signed informed consent to participate in the study. The clinical trial was conducted in accordance with the principles of the Declaration of Helsinki, adopted by the General Assembly of the World Medical Association, and the Council of Europe Convention on Human Rights and Biomedicine, as well as the International Council of Medical Scientific Societies and the International Code of Medical Ethics (Minutes No. 13 of the meeting of the commission on bioethics of Donetsk National Medical University from 07.11.2016). Before the restoration, in patients were determined the level of oral hygiene according to the Fedorov-Volodkina hygienic index and the intensity of carious lesions of the teeth, as well as carried out professional hygiene measures.

Teeth to be restored were cleaned of plaque with brushes and pastes that did not contain fluoride compounds, and determined the color of the teeth to match future restoration. Carious cavities were prepared, forming them for restoration with photocomposite material according to generally accepted requirements [18]. Next, total etching of the hard tissues of the bottom and walls of the prepared cavity with orthophosphoric acid gel was performed, after which the adhesive system of the 5th generation Single Bond 2, 3M ESPE was applied and affected by the light flux of the LED photopolymerizer under certain conditions. Tooth restoration was performed with Filtek Z550 nanophotocomposite material, 3M ESPE, in a layered technique with polymerization of each layer by light flux in the "soft start" mode. Finally, the finishing and polishing of the restoration was performed.

All examined patients were randomly divided into three groups. In 62 patients of the 1st group, the restoration of 62 teeth was performed with the polymerization of the 5 th generation adhesive 
system applied to the bottom and walls of the prepared carious cavity, the light flux of the LED photopolymerizer with a constant intensity of $1500 \mathrm{~mW} / \mathrm{cm}^{2}$. In 60 patients of group 2, the same adhesive system was used in 60 dental restorations, which was polymerized using a light flux of LED photopolymerizer in the "soft start" mode with a final intensity of $1500 \mathrm{~mW} / \mathrm{cm}^{2}$. During the restoration of 63 lateral teeth in 63 patients of group 3, the adhesive system was applied to the bottom and walls of the cavity, then with the help of the proposed nozzle on the fiber gradually affected the adhesive system on the bottom and each wall of the cavity for 20 seconds at a minimum distance from the surface of solid tissues and perpendicular to them with a light flux of LED photopolymerizer of constant intensity $1500 \mathrm{~mW} / \mathrm{cm}^{2}$.

The condition of the restorations was assessed the next day, as well as after 12 and 24 months with the leading, according to the purpose of the study, clinical criteria "marginal fit", "marginal staining", "secondary caries", "anatomical shape", "hypersensitivity" and according to aesthetic criteria "colour matching" and "surface roughness of the restoration" [19]. In the presence of violations in the recovery according to the leading criteria, patients were excluded from the study, in the case of an acceptable state of recovery, with the appropriate consent of patients, corrected, in the case of unacceptable state of recovery was performed again. In the presence of violations of the aesthetic criteria of recovery, with the consent, corrected, patients continued to be observed. It should be noted that quite often several violations were detected in one recovery, so the number of violations and restorations with them was registered in each group, as well as the number of restorations without violations, the number of which determined the clinical effectiveness of recovery. The results of the initial and subsequent examinations were entered into the medical records of the dental patient (form 043/o, approved by the Ministry of Health of Ukraine)

Variation statistics were used for statistical processing using the computer program Microsoft Excel. Significance of differences between the indices of hygiene indices and the intensity of dental caries was determined by Student's test, the differences were considered statistically significant at $\mathrm{p}<0.05$. Indicators of qualitative characteristics are presented in the form of absolute and relative values.

\section{Results}

During the initial examination before dental restoration, the state of oral hygiene according to the Fedorov-Volodkina hygienic index in patients of the three groups did not differ ( $\mathrm{p}>0.05)$; Thus, in patients of group 1 the hygienic index was $1.35 \pm 0.15$ points, in persons of groups 2 and $3-1.23 \pm 0.17$ and $1.44 \pm 0.14$ points, respectively, that is, in all patients the hygienic condition of the oral cavity was good. Indicators of the index of the intensity of dental caries in patients of these groups also had no statistically significant differences ( $p>0.05)$, they were equal to, respectively, $7.55 \pm 0.89 ; 6.95 \pm 0.74$ and $8.34 \pm 0.79$. The absence of statistically significant differences between the relevant indicators in patients of different groups indicates the identity of the study conditions.

The next day after the restoration in all restorations in patients of three groups of violations according to the studied clinical criteria were not detected, tooth restoration was in excellent condition, no complaints from patients were received.

After 12 months, all recoveries (100\%) in all patients (100\%) of the three groups were examined. It was found that patients of group 1 violated the marginal adhesion of the photocomposite material to the enamel of restored teeth in 7 restorations $(11.3 \pm 4.1 \%$ of the number of restorations in patients of this group), marginal colour was also detected in 7 restorations $(11.3 \pm 4.1 \%)$, while the depth of adhesion and colour penetration was only to the dentino-enamel limit, increased sensitivity of hard tissues was registered in 2 restored teeth $(3.2 \pm 2.3 \%)$. It should be noted that secondary caries was found in about 2 restorations $(3.2 \pm 2.3 \%)$, anatomical disorders were also found in 2 restorations $(3.2 \pm 2.3 \%)$. In total, according to the above clinical criteria, which are leading in the study of the polymerization of the adhesive system, 20 violations were identified, relating to 10 restorations $(16.1 \pm 4.9 \%)$. Other violations were identified by aesthetic criteria, in particular, the colour mismatch of the restoration material and hard tissues of the teeth within acceptable limits was found in 4 restorations $(6.5 \pm 3.2 \%)$, increased surface roughness -in 6 restorations $(9.7 \pm 3,8 \%)$. 
In patients of group 2 at this time of the examination, the violation of the marginal adhesion of the material within the enamel was determined in 9 restorations $(15.0 \pm 4.7 \%$ of the total number of restorations in this group), marginal staining at the border of photocomposite and hard tissues the border of enamel with dentin was established in 10 restorations $(16.7 \pm 4.9 \%)$, increased sensitivity of hard tissues was found in 4 restored teeth $(6.7 \pm 3.3 \%)$. It is important that secondary caries was diagnosed in 3 restored teeth $(5.0 \pm 2.7 \%)$ next to the photocomposite material from which the restorations were made, and the anatomical violation was in 1 restoration $(1.7 \pm 1.7 \%)$. Thus, according to the leading, from the point of view of the purpose of the study, clinical criteria, a total of 27 disorders were identified, which related to 13 restorations $(21.7 \pm 5.8 \%)$. Regarding aesthetic characteristics, the colour discrepancy was found in 5 restorations $(8.3 \pm 3.6 \%)$, and in 6 restorations $(10.0 \pm 3.9 \%)$ increased roughness of the material was found.

In 63 patients of the 3rd group, violations of the marginal adhesion of the material to the enamel border of the restored teeth were found in 2 restorations $(3.2 \pm 2.2 \%$ of the number of restorations in patients of this group), marginal staining with the depth of penetration also to the dentino-enamel border - in 3 restorations $(4.8 \pm 2.7 \%)$. No cases of hypersensitivity of hard tissues and secondary caries in restored teeth were found, only in 1 restoration $(1.6 \pm 1.6 \%)$ there was a violation of the anatomical shape. These indicators indicate that the total number of violations detected by the leading clinical criteria is 6 , they were found in 3 restorations $(4.8 \pm 2.6 \%)$. At the same time, aesthetic disorders are almost as many as in patients of other groups. Colour mismatch of the restoration within the allowable range was found in 5 restorations $(7.9 \pm 3.5 \%)$, increased surface roughness of the material - also in 5 restorations $(7.9 \pm 3.5 \%)$.

Restorations of teeth in which violations were found according to the leading clinical criteria were corrected with the consent of patients of all three groups, and patients with such restorations were excluded from the study. In the case of violations of aesthetic criteria, they were corrected, but patients with these restorations continued to participate in the study.

After 24 months, the number of examined patients was lower compared to the beginning of the study, in particular, 52 patients $(82.5 \%$ of the initial number) of 1 group with 52 restorations (82.5\% of baseline), 47 people $(78.3 \%$ ) of group 2 were examined, in which there were 47 restorations $(78.3 \%)$, the number of patients in group 3 was 60 people $(95.2 \%)$, the same was the number of restorations - $60(95.2 \%)$.

Examination of tooth restorations after 24 months in patients of group 1 showed that for the first time in the study there was found absence of 1 restoration $(1.9 \pm 1.9 \%$ of the number of restorations in this period in patients in this group). The number of restorations with disturbed marginal fit of the material increased to $11(21.2 \pm 5.8 \%)$, with marginal staining on the border of photocomposite material and enamel, 10 restorations $(19.2 \pm 5.6 \%)$ were detected, and the depth of these violations was within the enamel and partially entered the dentin. Secondary caries was diagnosed in 3 restored teeth $(5.8 \pm 3.3 \%)$, it was found near or under restorations, in 2 restorations $(3.8 \pm 2.7 \%)$ anatomical disorders were found. There were no cases of hypersensitivity of hard tissues in restored teeth. According to the leading criteria, a total of 27 violations were registered, taking into account the lack of recovery, relating to 16 restorations $(30.8 \pm 8.0 \%)$. Regarding the inconsistency of the restoration in colour, it was within acceptable limits found in 7 restorations $(13.5 \pm 4.8 \%)$, in terms of roughness, there were 8 such cases $(15.4 \pm 5.1 \%)$.

In patients of group 2, the number of detected disorders was even greater. First of all, there were absence of 2 restorations $(4.3 \pm 3.0 \%$ of the number of restorations in this group at this time). Violation of the marginal adhesion of the photocomposite material to the enamel and marginal staining at the restoration boundary was detected in 13 cases according to each of the criteria $(27.7 \pm 6.7 \%)$, their depth reached the dentino-enamel boundary and beyond. Secondary caries was diagnosed in 6 restored teeth $(12.8 \pm 5.0 \%)$, i.e. 2 times more than in the previous period, anatomical disorders - in 2 restorations $(4.3 \pm 3.0 \%)$. Hypersensitivity of hard tissues was not detected. The total number of violations according to the leading clinical criteria, taking into account the lack of restorations, reached 36, violations concerned, in total, 20 restorations $(42.6 \pm 10.4 \%)$. Colour discrepancy within the permissible limits was found in 7 restorations $(14.9 \pm 5.3 \%)$, increased roughness - also in 7 restorations $(14.9 \pm 5.3 \%$ ), such were the indicators according to aesthetic criteria. 
It should be noted that in patients of group 3 disorders were found significantly less frequently. Thus, there were only 3 cases of violation of the marginal fit of the material $(5.0 \pm 2.9 \%$ of the number of restorations in the group during this period), all of them were within the enamel, the same was the number of restorations with marginal colour $-3(5.0 \pm 2.9 \%)$. Hypersensitivity of hard tissues and secondary caries in the restored teeth did not occur, only in 1 restoration $(1.7 \pm 1.7 \%)$ anatomical disorders were found. Regarding the total number of violations according to the leading criteria, the persons of group 3 had the least of them - only 7 in 4 restorations $(6.7 \pm 3.2 \%)$. Colour mismatch and roughness of the material were found in the same amount, with such violations, in accordance with these aesthetic criteria, there were $6(10.0 \pm 3.9 \%)$.

\section{Discussion}

A study conducted over two years showed significant differences in the results in individuals of different groups, which increased with increasing follow-up. However, even within 12 months, the number of recoveries with violations according to the leading clinical criteria in patients of group 3 was 3.3 and 4.3 times less than the same number in patients of groups 1 and 2 , respectively $(\mathrm{p}<0.05)$. Within 24 months, the number of restorations with disorders in persons 1 and 2 groups was, respectively, 4 and 5 times more than the number of restorations with defects in the examined patients of group $3(p<0,05)$. In total, for two years of observation of the leading clinical criteria in patients of group 1 were found 47 violations in 26 restorations $(41.9 \pm 2.3 \%$ of the initial number of restorations in this group), in patients of group $2-63$ violations in 33 restorations $(55.0 \pm 2.8 \%$ of their original number), in persons of group 3 - only 13 violations in 7 restorations $(11.1 \pm 1.2 \%$ of the initial number). If we analyse the number of restorations in excellent condition, i.e. without violations, then such, according to the ordinal numbering of groups, in two observation periods, in particular, within 12 months, there were $52(83.9 \pm 3.3 \%$ of the initial number), $47(78.3 \pm 3.3 \%)$ and $59(93.7 \pm 3.4 \%)$, within 24 months $-36(58.1 \pm 2.8 \%$ of the initial amount), $27(45.0 \pm 2.5 \%)$ and $56(88.9 \pm 3.5 \%)$. The obtained results in percent in each of the terms were taken as indicators of clinical efficiency of recovery, they indicate the advantages of the proposed step-by-step light polymerization of the adhesive system at the bottom and each of the walls of the prepared carious cavity.

The need to improve the technology of direct restoration of teeth with photocomposite materials is confirmed by the results of other clinical studies. Violations of the marginal fit of the material within two years had $63.0 \%$ of the examined restorations, loss of fillings was registered in $19.2 \%$ of cases, secondary caries - in $37.0 \%$ of restored teeth [20]. In another study, after four years, marginal adhesion was found in $32 \%$ of restorations using self-etching adhesive systems and in $13 \%$ of restorations using pre-etched adhesive techniques, and marginal staining in $21 \%$ and $11 \%$ of restorations, respectively [21]. A significant number of disorders were detected according to these clinical criteria, the state of recovery of which depends in some way on the polymerization of the adhesive system that was used.

Study limitations. The study did not include persons under 18 years of age and over 44 , due to the presence of certain age-related features of caries and the dynamics of caries-resistant hard tissues of the teeth, as well as patients, in the case of teeth of the lateral group to be restored, there were already fillings or carious cavities; if the teeth were previously covered with artificial crowns; if antagonist teeth were absent, occlusion pathology, increased tooth abrasion, or bruxism were identified; in the presence of periodontal pathology (periodontitis, periodontitis) and unsatisfactory oral hygiene. Patients with somatic diseases that contribute to the reduction of caries of dental hard tissues or the development of periodontal disease, persons with mental disorders, including due to alcohol or drug addiction, as well as when patients simultaneously participated in another study or planned during the study moving to another city.

Prospects for further research. In the future, it is planned to continue clinical monitoring of patients with dental restorations, which were made of nanophotocomposite material in different conditions of polymerization of the adhesive system of the 5th generation, in order to obtain longterm clinical results.

Research is also planned on the development and clinical testing of additional tools that would ensure full curing of the adhesive system by light flux of LED photopolymerizer during 
direct restoration of teeth with photocomposite materials in different clinical situations, including carious cavities of different classes, and which would reduce time light exposure to the adhesive system at the bottom and each of the walls of the cavity in the restored teeth.

\section{Conclusions}

1. Carrying out direct restoration of teeth with carious cavities of 1 class according to Black from nanophotocomposite material using the 5th generation adhesive system with its gradual polymerization on the bottom and separately on each of the walls provides high efficiency, which according to leading clinical criteria is 12 months $93.7 \pm 3.4 \%, 24$ months $-88.9 \pm 3.5 \%$.

2. Light exposure to the adhesive system at the bottom and separately on each of the walls of the cavity should be carried out using the proposed nozzle on the light guide of the photopolymerizer, which directs the light perpendicular to the surface of hard tissues at a minimum distance from them.

3. The proposed conditions of light polymerization of the adhesive system ensure in the period of 12 and 24 months the absence of secondary caries in the restored teeth.

\section{Conflicts of interest}

The authors declare that they have no conflicts of interest.

\section{References}

[1] Dietschi, D., Shahidi, C., Krejci, I. (2019). Clinical performance of direct anterior composite restorations: a systematic literature review and critical appraisal. International Journal of Esthetic Dentistry, 14 (3), 252-270.

[2] Kolodii, Iu. R. (2017). Innovatsionnyi nanokompozitnyi material v stomatologi. Biulleten meditsinskikh internetkonferentsii, 7 (9), 1418-1419.

[3] Margvelashvili, M., Kalandadze, M., Viki, A., Gorrachi, Ch., Ferrari, M. (2013). Stomatologicheskie adgezivnye sistemy: perevod nauki. DentArt, 4, 14.

[4] Udod, A. A., Sahunova, K. Y. (2014). Adhezyvnie systemi v restavratsyonnoi stomatolohyy: evoliutsyia y perspektyvi. Visnyk problem biolohii i medytsyny, 2 (3 (109)), 53-57.

[5] Gilmiiarov, E. M., Radomskaia, V. M., Gilmiiarova, F. N. et. al. (2014). Manipuliatsionnye, esteticheskie svoistva, biosovmestimost sovremennykh adgezivnykh i plombirovochnykh materialov. Rossiiskii stomatologicheskii zhurnal, 3, 30-33.

[6] Cardoso, M., de Almeida Neves, A., Mine, A., Coutinho, E., Van Landuyt, K., De Munck, J., Van Meerbeek, B. (2011). Current aspects on bonding effectiveness and stability in adhesive dentistry. Australian Dental Journal, 56, 31-44. doi: http:// doi.org/10.1111/j.1834-7819.2011.01294.x

[7] Mahmoud, S. H., Al-Wakeel, E. S. (2011). Marginal adaptation of ormocer-, silorane-, and methacrylate-based composite restorative systems bonded to dentin cavities after water storage. Quintessence International, 42 (10), 131-139.

[8] Saykav, P., Alam, A., Sung, J., Carvalho, R. M., Sano, H. J. (2019). The effects of double application of modern self-etching adhesives on their dentin binding efficiency using clinically significant smear layers. Chowdhury AFMA. Ades Dent, 21 (1), 59-66.

[9] Song, L., Ye, Q., Ge, X., Misra, A., Tamerler, C., Spencer, P. (2016). Self-strengthening hybrid dental adhesive via visible-light irradiation triple polymerization. RSC Advances, 6 (57), 52434-52447. doi: http://doi.org/10.1039/c6ra09933e

[10] Borouziniat, A., Khaki, H., Majidinia, S. J. (2019). Retrospective evaluation of the clinical performance of direct composite restorations using the snow-plow technique: Up to 4 years follow-up. Journal of Clinical and Experimental Dentistry, 11 (11), e964-e968. doi: http://doi.org/10.4317/jced.55639

[11] Spencer, P., Ye, Q., Park, J., Topp, E. M., Misra, A., Marangos, O. et. al. (2010). Adhesive/Dentin Interface: The Weak Link in the Composite Restoration. Annals of Biomedical Engineering, 38 (6), 1989-2003. doi: http://doi.org/10.1007/s10439-010-9969-6

[12] Santos, M. J. M., Costa, M. D., Rêgo, H. M. C., Rubo, J. H., Santos, G. C. (2017). Effect of surface treatments on the bond strength of self-etching adhesive agents to dentin. General Dentistry, 65 (4), e1-e6.

[13] Udod, A. A., Bekuzarova, K. I. (2017). Izuchenie osobennostei polimerizatsii nanonapolnennykh adgezivnykh sistem. Aktualnye problemy sovremennoi stomatologii. Samarkand, 19-20.

[14] Werle, S. B., Steglich, A., Soares, F. Z., Rocha, R. O. (2015). Effect of prolonged air drying on the bond strength of adhesive systems to dentin. General Dentistry, 63 (6), 68-72.

[15] Soares, G. P., Silva, G. G., Ambrosano, G. M. B., Lima, D. A. N. L., Marchi, G. M., Lovadino, J. R., Aguiar, F. H. B. (2013). Effect of polymerization mode and time of adhesive system on microleakage in composite resin restorations. Journal of Investigative and Clinical Dentistry, 5 (4), 289-294. doi: http://doi.org/10.1111/jicd.12060 
[16] Bezvushko, E. V., Shpotiuk, O. O. (2017). Klinichna otsinka restavratsii iz kompozytnykh materialiv z urakhuvanniam hihiieny porozhnyny rota. Klinichna stomatolohiia, 2, 54-59.

[17] Borgia, E., Baron, R., Borgia, J. L. (2017). Quality and Survival of Direct Light-Activated Composite Resin Restorations in Posterior Teeth: A 5- to 20-Year Retrospective Longitudinal Study. Journal of Prosthodontics, 28 (1), e195-e203. doi: http:// doi.org/10.1111/jopr.12630

[18] Nykolaev, A. Y., Tsepov, L. M. (2017). Praktycheskaia terapevtycheskaia stomatolohyia. Moscow: MEDpressynform, 928.

[19] Ryge, G. (1998). Klinicheskie kriterii. Klinicheskaia stomatologiia, 3, 40-46.

[20] Ozhohan, I. A., Hereliuk, V. I., Ozhohan, Z. R. (2014). Analiz ekspertnoi otsinky restavratsii bichnykh zubiv. Ukrainskyi stomatolohichnyi almanakh, 4, 25

[21] Heintze, S. D., Rousson, V. (2012). Clinical Effectiveness of Direct Class II Restorations - A Meta-Analysis. The Journal of Adhesive Dentistry, 14 (5), 407-431. doi: http://doi.org/10.3290/j.jad.a28390

\title{
DOES THE TERM OF DEFINITIVE OSTEOSYNTHESIS OF MULTIPLE LONG BONE FRACTURES OF LOWER EXTREMITIES IMPACT ON TREATMENT OUTCOMES IN POLYTRAUMA PATIENTS
}

\author{
Olexandr Burianov \\ Department of Traumatology and Orthopedics ${ }^{1}$ \\ kaftraum@ukr.net \\ Sergii Dubrov \\ Department of Anesthesiology and Intensive Care ${ }^{1}$ \\ Intensive Care Unit ${ }^{2}$ \\ sergii.dubrov@gmail.com \\ Taras Omelchenko \\ Department of Traumatology and Orthopedics ${ }^{1}$ \\ tnomelchenko@gmail.com \\ Volodymyr Lianskorunskyi \\ Department of Traumatology and Orthopedics ${ }^{1}$ \\ Department of Polytrauma ${ }^{2}$ \\ lyanskorynsky@gmail.com \\ Viktor Lykhodii \\ Department of Traumatology and Orthopedics ${ }^{1}$ \\ viktorodoc@ukr.net \\ Myroslav Vakulych \\ Department of Traumatology and Orthopedics ${ }^{1}$ \\ vakulychmyroslav@gmail.com \\ ${ }^{1}$ Bogomolets National Medical University \\ 13 T. Shevchenko blvd., Kyiv, Ukraine, 01601 \\ ${ }^{2}$ Kyiv City Clinical Hospital No. 17 \\ 14-20 Laboratornyi str., Kyiv, Ukraine, 01133
}

